\title{
History, human rights and multilingual citizenship: conceptualising the European Charter for Regional or Minority Languages \\ R GWYNedd PARRY*
}

\author{
Swansea University
}

\section{Introduction}

$\mathrm{T}$ The paradox at the heart of the movement towards greater European political and economic union is the recognition of the need to acknowledge, protect and even celebrate the plurality and diversity of language, culture and national identity within the superstructure. Among the initiatives that have sought to bring about the preservation of European linguistic plurality the most notable has been the creation of the Council of Europe's European Charter for Regional and Minority Languages (ECRML). ${ }^{1}$

The ECRML is by far the most comprehensive and detailed international treaty concerned with the promotion of linguistic plurality in Europe. It is the ECRML, more than any other international treaty, that offers a blueprint for the development of a multilingual society based on equal citizenship, ${ }^{2}$ a political reality whereby linguistic minorities are integrated without sacrificing or abandoning their linguistic identity. ${ }^{3}$ The ECRML operates within a framework of an expanding body of international jurisprudence with an interest in minority language protection. Because there are now a number of international and domestic instruments that offer protection to speakers of minority languages in various ways, establishing the ECRML's place within the jurisprudential firmament is important.

The aims of this paper are to locate the ECRML and its objectives within the broader international context and to scrutinise its contribution to minority language protection by focusing on two key aspects. Firstly, it analyses the implications of its particular focus on the indigenous or historical minority languages of Europe and it considers the potential nexus between this historiography and national minority claims for political selfdetermination. Secondly, it evaluates the compatibility of historically based, particularised rights with universal human rights principles, with particular reference to the European Convention on Human Rights (ECHR).

\footnotetext{
* Senior Lecturer, School of Law, Swansea University.

1 ECRML, Strasbourg, 5 November 1992.

2 See, generally, W Kymlicka, Multicultural Citizenship: A liberal theory of minority rights (Oxford: Clarendon 1995).

3 For reflections on the citizenship of linguistic minorities, see C Taylor, "The politics of recognition" in C Taylor et al. (eds), Multiculturalism: Examining the politics of recognition (Princeton: Princeton UP 1994), pp. 25-73.
} 
The focus on protecting the historical or indigenous languages has been the source of some disquiet and criticism. Many language rights theorists have questioned whether the differentiation between historical and new linguistic groups has undermined the integrity and validity of the case for recognising linguistic rights as fundamental human rights. ${ }^{4}$ Indeed, for some, the ECRML's emphasis on the historical languages has the potential to diminish the value of linguistic rights and perceive it as being at odds with liberal, universal, rights-based principles. ${ }^{5}$

This paper confronts these concerns and examines to what extent the ECRML's historically based approach supports or undermines the cause of linguistic minorities and whether it can be reconciled with the universal emphasis in the ECHR. It thus critiques the treaty's distinctive historiography and evaluates its implications. In doing so, it further highlights the conceptual tension that exists between upholding universal human rights and recognising the rights of particular groups to special measures that are often pre-conditional to the realisation of their human rights.

\section{The ECRML in context}

Since the end of the Second World War, there has been a proliferation of international treaties and legal instruments with a stake in minority interests, including regional and minority languages and the individuals who speak those languages. On the global stage, the United Nations has, unsurprisingly, taken a leading role in setting standards. The often quoted exemplar, the International Covenant on Civil and Political Rights (ICCPR), Article 27, declares that linguistic minorities should not be denied their culture and the right to use their own language. ${ }^{6}$ The United Nations Declaration on the Rights of Persons belonging to National or Ethnic, Religious and Linguistic Minorities also supports the rights of minority cultures, although it does not amount to a binding legal instrument. ${ }^{7}$ This paper does not provide a detailed guided tour of the international jurisprudence in this field. ${ }^{8}$ In summary, the common theme is the maintenance of principles of anti-discrimination and non-interference so that linguistic minorities can enjoy linguistic freedom in the private sphere. Non-interference is, of course, not the same as active promotion of multilingualism on the part of the state.

In the context of the European Union, a degree of support for minority language interests can also be discerned. ' A multicultural entity composed of other multicultural entities, the EU has had an important role in providing a vision for a multicultural and

4 See R Dunbar, "Implications of the European Charter for Regional or Minority Languages for British linguistic minorities" (2000) 25 ELRev Human Rights Survey 46, at 50; T Cheesman "Old and new lesser-used languages of Europe: common cause?" in CC O'Reilly (ed.), Language, Ethnicity and the State, vol. 1(Basingstoke: Palgrave 2001), pp. 147-66.

5 See, further, P Keller, "Re-thinking ethnic and cultural rights in Europe", (1998) 18(1) Oxford Journal of Legal Studies 29-59; R Bauboeck, "Cultural minority rights for immigrants" (1996) 30(1) International Migration Review 203-50.

6 See ICCPR, Article 27. For an interpretation of the scope of ICCPR, Article 27, see Ominayak v Canada, UN 167/1984, Document A/42/40.

7 The United Nations' contribution to international human rights law is often hailed as being one of its "great accomplishments": see H Herman, "Human rights" in CC Joyner (ed.), The United Nations and International Law (Cambridge: CUP 1998), pp. 130-54, at p. 153.

8 For a more detailed guide to the range of applicable international instruments, see F de Varennes, "Linguistic identity and language rights" in M Weller (ed.), Universal Minority Rights: A commentary on the jurisprudence of international courts and treaty bodies (Oxford: OUP 2007), pp. 253-323, at p. 255-8.

9 For commentary on the position of linguistic rights in European Law, see I Urrutia and I Lasagabaster, "Language rights and community law" (2008) 12(4) European Integration Online Papers, http://eiop.or.at/eiop/texte/2008-004a.htm. 
multilingual society. Perhaps, as a cultural expression of the principle of subsidiarity, the rationale of the EU's policy is one of normalised linguistic diversity on the basis of "unbiased coexistence". ${ }^{10}$ The European Commission appointed a commissioner with responsibility for education, training, culture and multilingualism in November 2004. His brief was to promote "the peaceful co-existence of people from many different language communities", and to facilitate the protection of cultural identity and linguistic diversity. ${ }^{11}$

European Law has for some time, albeit perhaps tentatively, supported a policy of cultural diversity. Article 151 EC promoted cultural diversity within Europe, although there was no specific mention of linguistic diversity in this provision. However, European law gradually began to engage with the notion of linguistic rights within the concept of European citizenship, particularly following the case of $\mathrm{R} e$ Criminal Proceedings against Horst Otto Bickel and Ulrich Franz: ${ }^{12}$ That case upheld the principle that Article 6 EC precludes national rules that confer on its own citizens the right to require that criminal proceedings be conducted in a particular language, without conferring the same right on nationals of other member states who may be subject to criminal proceedings in that region.

More recent developments potentially herald greater support for linguistic diversity within EU law. The European Charter of Fundamental Rights enshrines the core values of the European Union in a consolidating instrument. ${ }^{13}$ The European Union's Reform Treaty (the Lisbon Treaty) ${ }^{14}$ provides a legal base for the Charter of Fundamental Rights (provided that member states ratify both). ${ }^{15}$ Article 21 of the Charter of Fundamental Rights advances the principle of linguistic rights within the European Union and creates means of redress and appeal in cases of discrimination on the grounds of language or where an individual is a member of a national minority. Such appeals will go to the European Court of Justice in Luxembourg. Article 21.1 states that:

any discrimination based on any ground such as sex, race, colour, ethnic or social origin, genetic features, language, religion or belief, political or any other opinion, membership of a national minority, property, birth, disability, age or sexual orientation shall be prohibited.

Article 22 of the Charter of Fundamental Rights states that: "The Union shall respect cultural, religious and linguistic diversity." In addition, Article 3.3 of the Lisbon Treaty declares that the European Union: "shall respect its rich cultural and linguistic diversity, and shall ensure that Europe's cultural heritage is safeguarded and enhanced". Linguistic groups are thus provided with some grounds for redress if they are discriminated against in any European Union legislation. The Charter of Fundamental Rights is intended to complement other international instruments, such as the ECHR, which protect individuals who belong to minorities. A Fundamental Rights Agency (FRA) will be able to monitor and make reports on discrimination, as well as promoting general awareness of minority language issues. The Lisbon Treaty, by giving a binding effect to the Charter of Fundamental Rights, broadens the influence of the European Union in the field of individual rights. It also unequivocally engages the jurisdiction of the European Court of Justice in cases of discrimination.

10 N Nic Shuibhne, EC Law and Minority Language Policy: Culture, citizenship and fundamental rights (London: Kluwer Law International 2002), p. 55.

11 See http://europa.eu/debateeurope/pdf/figel_062006_en.pdf.

12 Case C-274/96 ECJ [1999] 1 CMLR 348.

13 The Charter of Fundamental Rights: http://europa.eu.int/comm/justice_home/unit/charte/en/charterequality.html.

14 http://europa.eu/lisbon_treaty/index_en.htm.

15 The United Kingdom and Poland have opted out of the Charter of Fundamental Rights. 
Of course, it remains to be seen to what extent these recent developments will advance the cause of linguistic rights in a positive and practical way in the medium to long term. The emphasis is largely on preventing discrimination rather than on conferring any rights to speakers of minority languages, and in that sense replicates UN activity in this field. The Council of Europe, however, has been the source of more pro-active standards on minority language promotion. The Council of Europe's Framework Convention for the Protection of National Minorities deals with language rights within the broader context of minority rights. ${ }^{16}$ For example, Article 10(1) of the Framework Convention recognises the right to use a minority language in public and private life. Article 14(1) of the Framework Convention deals with education, but it is couched in very general and limited terms. Article 14(1) requires "the parties undertake to recognise that every person belonging to a national minority has the right to learn his or her minority language", and Article 14(2) requires parties, subject to caveats, to provide adequate opportunities for being taught in the minority language. The difficulty with the Framework Convention, as with many of the other international instruments is that, although it promotes worthy sentiments towards minority languages and cultures, it is weak on detail and specifies few practical measures in the interests of linguistic minorities. ${ }^{17}$ It is in the detail and emphasis that the ECRML stands out from the crowd. ${ }^{18}$

The ECRML is significant because it is wholly concerned with linguistic minority rights, and requires states to implement certain defined measures in the interests of minority languages. Part III of the ECRML lists the obligations that states should undertake to promote regional or minority languages. Articles 8 to 14 specify obligations for states in the fields of education, law, public administration, media, culture and economic and social life. Of the total range of obligations set out in Part III, states are required to apply a minimum of 35 , about half of the total number of obligations found within the ECRML. The ECRML adopts an á la carte system of adoption in that states have a considerable freedom to choose those obligations to which they wish to subscribe in the interests of particular languages. ${ }^{19}$ It is thereby flexible in its capacity to take into account the diversity that exists between minority languages within European states. ${ }^{20}$ It also encourages gradual, progressive compliance with the ECRML as opposed to immediate, excessive and overambitious subscription to its obligations. ${ }^{21}$ The often repeated criticism of the ECRML is that it gives states too much discretion to apply it according to their own political priorities. However, this flexibility can also be a virtue in the context of the complex and diverse linguistic landscape that exists within Europe as a whole. ${ }^{22}$

16 See M Weller (ed.), The Rights of Minorities: A commentary on the European Framework Convention for the Protection of National Minorities (Oxford: OUP 2005); see also, S Wheatley "The Council of Europe's Framework Convention on National Minorities" (1996) 5 Web JCLI.

17 For a study of the mechanisms to implement and monitor minority rights, see RM Letschert, The Impact of Minority Rights Mechanisms (The Hague: TMC Asser 2005).

18 For an overview, see R Dunbar, “The Council of Europe's European Charter for Regional or Minority Languages" in K Henrard and R Dunbar (eds), Synergies in Minority Protection (Cambridge: CUP 2008), pp. 155-85.

19 This is subject to a few qualifications and a certain quota, namely that they must apply at least three paragraphs from each of Articles 8 and 12 and one paragraph from each of Articles 9, 10, 11 and 13. See ECRML, Part I, Article 2, para. 2.

20 See R Dunbar, "Definitely interpreting the European Charter for Regional or Minority Languages: the legal challenges" in R Dunbar and G Parry (eds), The European Charter for Regional or Minority Languages: Legal challenges and opportunities (Strasbourg: Council of Europe Publishing 2008), pp. 37-61, p. 40.

21 J-M Woehrling, The European Charter for Regional or Minority Languages: A critical commentary (Strasbourg: Council of Europe Publishing 2005), pp. 137-9.

22 See Dunbar, "Implications", n. 4 above, p. 69. 
Although there is no enforcement mechanism, there is a monitoring system, and states must report on their implementation of the ECRML within one year of ratification followed by reporting at three-yearly intervals thereafter. The reports are scrutinised by an independent panel of experts appointed by the Council of Europe, who in turn report their findings to the Council of Ministers. ${ }^{23}$ The monitoring process, despite its limitations, provides a mechanism for ensuring a level of public accountability for the implementation of the ECRML by states that are party to it. ${ }^{24}$

The ECRML's detail and pro-active emphasis marks it out from the other international instruments. Take, for example, the use of a minority language in a court trial. Article 6 of ECHR simply guarantees basic comprehension on the basis of linguistic necessity. It guarantees the right to use a minority language as part of the basic tenets of a fair trial. ${ }^{25}$ Article 6 ECHR provides that a person on trial must be understood and has a right to understand the proceedings. But the right under Article 6 to an interpreter where the defendant does not understand the language of the court is not the same as a right to use the language of choice, or the right to a tribunal that speaks the defendant's language. ${ }^{26}$ This principle of necessity has been maintained in other situations where individuals have unsuccessfully sought the support of the ECHR when seeking to use the language of their choice. ${ }^{27}$ We shall be returning to assess the ECHR's significance later in this article.

Article 10(3) of the Framework Convention for the Protection of National Minorities requires party states to guarantee the right of an individual to be informed in a language that he or she understands, the reasons for his or her arrest and the nature of the accusation, and to be able to defend himself or herself in that language (if necessary, with the assistance of an interpreter). The wording of Article 10(3) is so similar to that of Article 6 of the ECHR, that it is doubtful that it creates any further right at all, as it appears to promote linguistic comprehension rather than linguistic choice, which is no more than the basic human right protected by Article 6 of the ECHR. Again, as with the ECHR, it is the principle of linguistic necessity that the Framework Convention upholds.

The ECRML, however, goes much further. Article 9 ECRML takes the position from one of linguistic necessity to one of linguistic equality. It requires states, in appropriate circumstances, to allow speakers of the minority language to use it in court and tribunal hearings. ${ }^{28}$ The right to use the minority language in court proceedings applies to defendants, witnesses and all parties. Other provisions require criminal courts, at the request of one of the parties, to conduct proceedings in the minority or regional language ${ }^{29}$ and guarantee the accused the right to use his or her minority language. ${ }^{30}$ There are similar

23 ECRML, Part III, Article 15.

24 See also, T Skutnabb-Kangas, "Linguistic diversity, human rights and the free market", in M Kontra, $\mathrm{R}$ Phillipson, T Skutnabb-Kangas and T Varady (eds), Language: A right and a resource (Budapest: CEU Press 1999), pp. 187-222, at pp. 204-06.

25 See ECHR, Article 6.

26 This has been made clear in a number of judgments, see, for example, Av France (1984) 6 EHRR CD 371.

27 In Fryske Nasjonale Partij and Others v Netherlands (1987) 9 EHRR CD 261, speakers of Frisian complained about the refusal of authorities in the Netherlands to allow them to use the Frisian language when submitting relevant parliamentary election registration documents. The commission again held that there had been no breach of Convention rights, and there was no right to use the language of one's choice within the articles of the Convention.

28 ECRML, Part III, Article 9.

29 Ibid. Article 9, para. 1(a)(i).

30 Ibid. para. 1(a)(ii). 
provisions in the context of civil proceedings ${ }^{31}$ and also in the administrative courts. ${ }^{32}$ The ECRML provides that the use of the minority language is facilitated, if necessary, by means of interpreters and translation. ${ }^{33}$ The key difference is that the provisions of Article 9 are not dependant on the individual not being able to understand the dominant language, but introduces the principle of linguistic choice. It thus brings the position nearer to that of linguistic equality.

The ECRML, in light of its emphasis and detail, is unlike the other international instruments with their limited focus on preventing discrimination. However, it is also limited in its capacity to make a direct impact, because it is not part of European law, it does not grant individual legal rights nor does it create legal obligations and it has no judicial enforcement mechanism in the event of non-compliance. Nevertheless, it does have a valuable role in declaring international standards that can provide a reference point or benchmark for promoting multilingualism and linguistic diversity as a social value. ${ }^{34}$ The ECRML provides a set of values, international norms, that guide European states in their policies towards minority languages. It provides a shopping list in the form of practical measures that can facilitate minority language protection and promotion. Also, it is possible that, by signing up to the ECRML's obligations, states will then create laws that thereby create legal rights for speakers of those languages. ${ }^{35}$ This is because states that adopt certain measures, in order for that adoption to be effective, may need to legislate at a domestic level. But it is not the ECRML that is the sovereign or authority for the laws created internally by states, even where those laws were inspired by its provisions. While recognising that minority languages may not enjoy the same status as the official languages, its objective is to promote the concept of a multilingual society based on principles of respect and harmonious coexistence. ${ }^{36}$

\section{The ECRML and the use of history}

The ECRML is also distinctive in that promotes not simply minority languages, but the indigenous or historical languages of European peoples. It "covers only historical languages, that is to say languages which have been spoken over a long period in the state in question". ${ }^{37}$ As is clearly stated in Article 1, the languages that are protected are those spoken by a minority, are traditionally used by part of the population of a state, and are not official languages, languages of migrants, dialects or artificially created languages. ${ }^{38}$

The ECRML is concerned with "the historical regional or minority languages of Europe", because, it maintains that they contribute "to the maintenance and development of Europe's cultural wealth and traditions". ${ }^{39}$ The languages of new, migrant peoples, however, do not come under its remit. ${ }^{40}$ Its interest in multilingualism, therefore, does not

31 ECRML, Part III, Article 9, para. 1(b).

32 Ibid. para. 1(c).

33 Ibid. Part I, Article 1, para. (b).

34 Woehrling, The European Charter, n. 21 above, pp. 19-23.

35 Ibid. p 31.

36 Ibid. pp. 33 and 36-7.

37 ECRML, Explanatory Report, para. 31.

38 ECRML, Part I, Article 1: "The term regional or minority languages means languages that are, i. traditionally used within a given territory of a State by nationals of that State who form a group numerically smaller than the rest of the State's population, and, ii. different from the official language(s) of that State; it does not include either dialects of the official language(s) of the State or the languages of migrants."

39 ECRML, Preamble.

40 ECRML, Explanatory Report, paras 10 and 15. 
include new linguistic minorities, such as those minorities of Asian or African origin that are now well-established in most European states. Repeatedly, the emphasis is on the "common heritage", and on the "traditional regional and minority languages". 41 This distinction between old minorities and new minorities is replicated within the domestic legislation of many of the ratifying states, which have granted certain civic rights to indigenous minority linguistic groups but not to the more recently formed minority linguistic groups. ${ }^{42}$

The ECRML appears to justify its position on the grounds of heritage conservation. In essence, this justification maintains that Europe is a great linguistic safari park, and so the rare, indigenous species must be protected. The newcomers do not face linguistic extinction. On the contrary, many of these languages originate in parts of the world where over-population is the norm. Selective protection is thus justified on environmental grounds, that is, the protection of the human, cultural environment. Yet, this purported justification is not entirely convincing when it is realised that some of the languages protected by the ECRML are not in danger of extinction. Swedish is protected in Finland although it has a homeland where it is the dominant language. The status of German in Denmark is another example. Upon closer examination, the heritage conservation justification fails to encapsulate completely the ECRML's rationale.

A potential alternative to the conservationist theory might be a form of social contract theory. Such a theory might explain the ECRML's rationale on the basis that certain immigrant groups are deemed to have consented (normally by implication) to certain terms and conditions upon being accepted into a new society. It would draw on a notion of voluntary cultural adjustment, in that the new immigrant groups are deemed to have arrived on the understanding that they were required to integrate into the existing, dominant culture, and not supplant or undermine it. The older languages, on the hand, are spoken by peoples of Europe who did not "arrive" in an established society, but who were already present, and were never given the option of accepting the terms and conditions or otherwise return to another place of origin. ${ }^{43}$

Both the conservationist and social contract models have their attraction, especially the conservationist motive with its contemporary resonances. But upon careful reflection we see that both are derived from the same root in that both defend the special treatment of certain linguistic groups through the invocation of history. The heritage conservation basis must draw upon history to justify and explain its selection of languages that are to be regarded part of the linguistic heritage. The social contract model, and its use of the tacit consent argument, can only work if by means of historical enquiry we find that it is feasible to argue that certain linguistic immigrant peoples did find themselves in a politically ordered society, and that, by implication, they were expected to conform within that society's already established political regime. Conversely, using the same reasoning, the historical narrative maintains that the older linguistic communities were required to assimilate either contrary to their desires or without having been consulted about the matter.

Surprisingly, there has been little open debate on the historiography that underlines the ECRML's rationale. Historical rights often figure in discussions on the case for protection,

41 ECRML, Explanatory Report, para. 26.

42 The United Kingdom has recognised its obligations under the Charter for Welsh, Irish Gaelic, Scottish Gaelic, Scots, Ulster Scots and Cornish. For an overview, see R Dunbar, "Is there a duty to legislate for linguistic minorities?" (2006) 33(1) JLS 181-98.

43 For further reflections on social contract theory, see W Kymlicka, "Language policies, national identities, and liberal-democratic norms" in C Williams (ed.), Language and Governance (Cardiff: University of Wales Press 2007), pp. 505-15, at p. 506. 
but in a very casual, taken-for-granted way. The ECRML's use of history can be said to occur in two ways. First of all, history is used as a means of authenticating or validating linguistic status and entitlement to protection. The languages that enjoy protection do so in the light of their origins, their antiquity or their experience as victims of the past. The past is therefore the means of proving status as an indigenous language, or, of the language's status as the victim of past injustices, be they wars, arbitrary boundary changes, or forcible population displacement. Cornish is a language that enjoys some protection under the ECRML in the UK. It has very few speakers, probably no native speakers, and little real, visible presence even in its traditional heartland of west Cornwall. Yet, its right to protection under the ECRML is verified by reference to its history as an indigenous British (in its original meaning) language that survived the Anglo-Saxon displacement of Celtic culture in England during the sub-Roman era. ${ }^{44}$

As well as determining status, history also becomes a means of legitimising present and future claims for protection and promotion. Indeed, the promotion of the relevant language becomes a form of historical reparation. Accordingly, making up for past wrongs or injustices becomes the imperative, rather than the promotion of linguistic plurality as a universal and neutral value. It has interesting parallels with other political movements which promote a "coming to terms with the past" approach in order to offer apology and, possibly, reparation and repatriation. ${ }^{45}$ With this approach, history becomes the validating source of a language's right to protection under the ECRML.

There can be no doubt that many of the languages protected by the ECRML were the victims of historical assimilation movements or state border change, often a result of war or some other imposed political settlement. They consequently found themselves as minorities in larger political units, often multi-national states, processes that climaxed with the emergence in the nineteenth century of the modern nation-state. They were rarely asked to agree or consent to being absorbed within the newly created political supra-entity. As one observer comments, "national minorities and indigenous peoples did not come to the state (as with immigrants); rather the state came to them through some process (voluntary or involuntary) of territorial expansion". ${ }^{46}$

This emphasis on the historical or indigenous languages, therefore, has its political resonances. Promoters of the ECRML face a fundamental, self-evident truth, which is that many of the languages protected by it are, put simply, the languages of nations that were at a point in history incorporated into larger states. The linguistic agenda at a local level can therefore be an aspect of a broader nationalist movement rather than a product of some non-political or liberal cultural diversity agenda. ${ }^{47}$ In Wales, for example, the language issue has traditionally been driven by groups or individuals who have also promoted a nationalist, political drive for self-determination. ${ }^{48}$ This close nexus between the language revitalisation and political autonomy agendas has, occasionally, been detrimental to both the linguistic and political causes, mutatis mutandis. The political argument for greater self-determination has sometimes been treated with suspicion by the English-only speaking majority due to fears of hidden linguistic agendas that might eventually lead to their marginalisation as a linguistic

44 See, generally, C Thomas, Celtic Britain (London: Thames \& Hudson 1986).

45 J Black, Using History (London: Hodder Arnold 2005), pp. 92-3.

46 See Kymlicka, "Language policies", n. 43 above, at p. 506.

47 Ibid. pp. 509-15.

48 The important cultural dimension in the story of national rebirth in Wales has been acknowledged in many of several major historical studies. See, for example, KO Morgan, Rebirth of a Nation, A bistory of modern Wales (Oxford: OUP 1981); alternatively see DG Evans, A History of Wales 1906-2000 (Cardiff: University of Wales Press 2000). 
group. Conversely, the language revitalisation agenda has sometimes encountered opposition based on a fear that it might lead to, or at least provide sustenance for, claims for political separation. ${ }^{49}$ Detrimental or not, it is doubtful that the language agenda would have ever surfaced let alone enjoyed a degree of political success were it not for the efforts of nationalist campaigners. ${ }^{50}$

Of course, the link between language and nationhood is not always clear or straightforward. Not every linguistic community is harbouring serious ambition for selfgovernance as a linguistic group. In Scotland, for example, there is no political drive for independence on the part of either Gaelic speakers or Scots speakers in an effort to somehow undo the unity of Scotland brought about in the eleventh century. Gaelic speakers and Scots speakers do not regard themselves as nations by virtue of language. The claim of these linguistic communities is for recognition and protection within a larger, multilingual political entity, be that Scotland or the United Kingdom. ${ }^{51}$ But there can be no doubt that by looking at Europe as a whole we see that there is a tangible political nexus between language, culture and national identity. ${ }^{52}$

The Canadian political theorist, Will Kymlicka, also acknowledges this potentially potent connection between the emphasis on historical injustice and the cause of nationhood. $\mathrm{He}$ argues that the demands of small nations for greater national and political autonomy, of which cultural and linguistic autonomy are important aspects, have become acceptable in western Europe, and seen as being compatible with liberal-democratic values and notions of justice. ${ }^{53}$ If so, the discrimination between historical and immigrant linguistic groups may be defensible because, in the case of the former, their claims are firmly wedded to a broader national autonomy agenda rather than purely in terms of cultural diversity claims. Conversely, however, such nationalist claims are not as sympathetically considered by central and eastern European states, which see secessionist movements as being a threat to state security and a menace to international stability. ${ }^{54}$

Certainly, within Europe as a whole, the notion of "historical injustice" is interpreted and used in complex and diverse ways when it comes to national minorities. ${ }^{55}$ Whereas in western Europe, there is, generally speaking, a greater consensus on the historical minorities that are victims and deserve protection, in central and eastern Europe the picture is far from straightforward. This is due to the legacy of conquest and colonisation, and of changing positions of power among the peoples concerned. Although in western Europe we find a historical continuity of position between the dominant and minority languages, in eastern Europe the positions have changed repeatedly over time, so that languages that once represented the dominant authority have become minority languages, and suppressed languages have now achieved dominance.

49 This nexus between political separatism and cultural rights has also been noted by external observers; see CGA Bryant, The Nations of Britain (Oxford: OUP 2006), at pp. 117-56.

50 See D Phillips, Trwy Ddulliau Chwyldro . . . ? Hanes Cymdeithas yr Iaith Gymraeg, 1962-1992 (Llandysul: Gomer 1998).

51 For some legal-historical perspectives, see H MacQueen, "Laws and languages: some historical notes from Scotland” (2002) 6(2) Electronic Journal of Comparative Law http://law.kub.nl/ejcl/62/art62-2.html.

52 For further reflections, see $\mathrm{K}$ Henrard, "The interrelationship between individual human rights, minority rights and the right to self-determination and its importance for the adequate protection of linguistic minorities" (2001) 1 (1) Global Review of Ethnopolitics 41-61.

53 Kymlicka, "Language policies", n. 43 above, pp. 509-15.

54 See W Kymlicka, "Justice and security in the accommodation of minority nationalism" in S May, T Modood and J Squires (eds), Ethnicity, Nationalism and Minority Rights (Cambridge: CUP 2004), pp. 144-75.

55 Ibid. pp. 154-6. 
The potential consequence of this is that, in historical terms, the languages of former colonial powers might not be regarded as "deserving" protection, because they represent the authors of a past injustice as opposed to being victims of it. These historically based conflicts and their enduring and, sadly, damaging influence on contemporary debates can be seen in the troubled relationship between Turkey and Greece. Neither state has ratified either the Framework Convention or the ECRML, failures that reflect both states' problematic attitude towards their respective Turkish and Greek minorities. ${ }^{56}$ The burden of history weighs heavily on the political discourse in this particular conflict as it can in other instances where the legacy of the past is yet to be fully resolved. ${ }^{57}$

The question is whether the historiography, which is deeply imbedded in the ECRML's rationale, besides running counter to multilingualism as a universal value, is counterproductive and, indeed, fuelling the historical flames. Is this particular concern for indigenous minority languages and the apparent emphasis on facilitating historical justice, therefore, politically problematic? Of further significance is the fact that the ECRML does not provide a definitive list of those languages that it protects. ${ }^{58}$ Definition, interpretation and application are matters left to the state governments. Although this might appear to give it the advantage of flexibility and adaptability, allowing ratifying states to specify which languages within their respective territories are to be protected might also be a source of controversy.

This is because it potentially leaves minority language policy at the mercy of political expediency. ${ }^{59}$ Political imperatives can often shape and influence state use of history in justifying cultural policy, ${ }^{60}$ because "issues of national identity are centrally involved". 61 Public history often involves a selective use of historical narrative to support a very contemporary agenda and to legitimise present priorities. ${ }^{62}$ Deciding on what is heritage, and what is not, involves subjective, if not politically biased decisions. ${ }^{63}$ The political dimensions that underpin the popular historical narrative can often overwhelm the quest for

56 The failure to honour the rights of minorities has been the subject of repeated criticism by the Council of Europe. See http://assembly.coe.int/ASP/NewsManager/EMB_NewsManagerView.asp?ID=4493: also www.aina.org/news/20100127195356.htm.

57 For a further example of a complex relationship between the past and the present in shaping national policy, see B Bowring and M Antonovych, "Ukraine's long and winding road to the European Charter for Regional or Minority Languages" in Dunbar and Parry, The European Charter, n. 20 above, pp. 157-82.

58 See Woehrling, The European Charter, n. 21 above, pp. 53-7.

59 The potentially destructive role of history as a nutrient of state propaganda was witnessed in the Serbian response to Kosovo's unilateral declaration of independence. The Serbian account maintained that Kosovo is rightfully Serbian, and according to the popular tradition, taken wrongfully in 1389 by the Ottomans and later colonised by Albanian usurpers. Time and time again, Serbian resistance to Kosovo's right to independence turned to this historical narrative that purportedly supported Serbian claims to sovereignty. See, further, Black, Using History, n. 45 above, p. 9; also M Ferro, The Use and Abuse of History (London: Routledge 2003), pp. 1-20.

60 See, among others, J Arnold, K Davies and S Ditchfield (eds), History and Heritage: Consuming the past in contemporary culture (Shaftesbury: Donhead 1998).

61 Black, Using History, n. 45 above, p. 2.

62 See GG Iggers, Historiography in the Twentieth Century (Middletown: Wesleyan UP 2005), at pp. 149-60.

63 See, further, A Green and $\mathrm{K}$ Troup, The Houses of History: A critical reader in twentieth-century bistory and theory (Manchester: Manchester UP 1999), at pp. 230-7. 
objective truth. ${ }^{64}$ Indeed, the very word "heritage" has developed connotations with antihistory, with state and popular myth-making. 65

By adopting a historical or heritage-based approach to its promotion of multilingualism, is the ECRML courting political controversy and providing support for nationalist agendas within European states? The ECRML endeavours to distance itself from the political mire by promoting the concept of multilingualism within the unitary state. In particular, Article 5 provides a rule for interpreting the ECRML that prevents any conflict with the charter of the United Nations. In particular, it prevents the ECRML being used to undermine principles of international law governing national sovereignty or territorial integrity. It states that:

nothing in this Charter may be interpreted as implying any right to engage in any activity or perform any action in contravention of the purposes of the Charter of the United Nations or other obligations under international law, including the principle of the sovereignty and territorial integrity of States. ${ }^{66}$

Article 5 claims that the ECRML is not an instrument to undermine the authority of European states by promoting political autonomy for national/linguistic groups or justifying intervention on behalf of those groups by other states or the wider international community. The explanatory report embellishes on the provisions of the article by stating that "the protection and promotion of regional or minority languages which is the objective of the charter must take place within the framework of national sovereignty and territorial integrity". ${ }^{67}$ The Preamble also outlines the overriding purpose and rationale of the treaty in upholding the values of "inter-culturalism and multilingualism" and proclaims that:

the protection and promotion of regional or minority languages in the different countries and regions of Europe represent an important contribution to the building of a Europe based on the principles of democracy and cultural diversity within the framework of national sovereignty and territorial integrity. ${ }^{68}$

Woehrling also comments that Article 5 affirms the ECRML's commitment to international law and that "the charter cannot legally have the effect of calling into question the aims of the Charter of the United Nations". ${ }^{69}$

It is a well-established principle of international law that states should enjoy respect for their sovereignty and territorial integrity. This was the foundation for world peace as declared in the Charter of the United Nations. After all, the overriding objective in setting up the United Nations was to maintain international peace and security and "to bring about by peaceful means, and in conformity with the principles of justice and international law, adjustment or settlement of international disputes or situations which might lead to a breach of the peace". 70 The creation of the United Nations was a key component of the post-Second World War reconstruction agenda and at the very heart of the new world order. Its cardinal purpose was to prevent war and aggression and to guarantee the security of all state members. As has been said, "Most of the fundamental norms, rules and

64 For historiographical critiques of notions of "truth" in history, see W Thompson, Postmodernism and History (Basingstoke: Palgrave 2004); H White, The Content of the Form: Narrative discourse and historical representation (Baltimore: Johns Hopkins UP 1987); EM Wood and JB Foster (eds), In Defense of History: Marxism and the postmodern agenda (New York: Monthly Review Press 1997); J Warren, The Past and its Presenters: An introduction to issues in historiography (London: Hodder \& Stoughton 1998), pp. 163-71.

65 See Ferro, Use and Abuse, n. 59 above, p. 359.

66 ECRML, Part 1, Article 5.

67 ECRML, Explanatory Report, para. 55.

68 ECRML, Preamble.

69 Ibid.

70 UN Charter, Article 1(1). 
practices of international relations rest on the premise of state sovereignty . . nonintervention is the duty correlative to the right of sovereignty. Other states are obliged not to interfere with the internal actions of a sovereign state." 71

Interference with the domestic jurisdiction of states can thus amount to a breach of Article 2(7) of the Charter of the United Nations, and the threat or use of force against the territorial integrity of states can likewise contravene Article 2(4) of the Charter of the United Nations. Article 2(4) states that: "All Members shall refrain in their international relations from the threat or use of force against the territorial integrity or political independence of any state, or in any other manner inconsistent with the Purposes of the United Nations." 72

These are the provisions of the United Nations Charter to which Article 5 ECRML refers and upholds. The explanatory report gives further guidance on what exactly Article 5 is seeking to achieve when it states:

the fact that, by ratifying the charter, a state has entered into undertakings with respect to a regional or minority language may not be used by another state having a special interest in that language or by the users of the language as a pretext for taking any action prejudicial to the sovereignty and territorial integrity of that state. ${ }^{73}$

Perhaps it is this particular passage in the explanatory report that is most instructive in explaining the inclusion and content of Article 5 in the ECRML. It ensures that the ECRML cannot be interpreted in such a way that it gives the authority to a state to interfere in the interests of a linguistic group in another state. For example, in theory, it prevents Sweden from drawing upon the ECRML as a basis for interjecting on behalf of Swedish speakers in Finland, or Germany to intervene on behalf of German speakers in Denmark.

The need to declare this injunction, and thus compatibility with the United Nations Charter, may have historical resonances, and may be a response to the inter-war experience of minority protection within international affairs. In the inter-war period (1918-39), the purported claims of linguistic and national minorities had been manipulated and used, most notably by Germany, to justify military intervention in neighbouring states. ${ }^{74}$ The ECRML's rejection of this form of political manipulation of its objectives is to declare its compatibility with the principle of national sovereignty and state integrity and to make it clear that it does not challenge the territorial boundaries of states and does not "identify distinctive territorial entities which would present a challenge to state integrity". 75

Perhaps the need for the inclusion of Article 5 also reflects the fact that the ECRML came into existence when the fragmentation of established political order in the Balkans was reaching its climax with the disintegration of Yugoslavia. ${ }^{76}$ This may have created wariness in some quarters of a treaty that promoted the rights of linguistic minorities and that might, indirectly and by extension, also promote the cause of national minorities seeking political autonomy. The provisions of Article 5 were thus necessary as part of the

71 See J Donnelly, "State sovereignty and international intervention: the case of human rights" in GM Lyons and M Mastanduno (eds), Beyond Westphalia? State sovereignty and international intervention (Baltimore: Johns Hopkins UP 1995), pp. 115-46, at p. 118.

72 UN Charter, Article 2(4).

73 See ECRML, Explanatory Report, para. 55.

74 See de Varennes, "Linguistic identity", n. 8 above, pp. 254-5.

75 Woehrling, The European Charter, n. 21 above, p. 86.

76 Much has been written on this subject. See, for example, B Magas, The Destruction of Yugoslavia: Tracking the break-up 1980-1992 (London: Verso 1993); M Glenny, The Fall of Yugoslavia: The third Balkan war (London: Penguin 1992). 
diplomatic trade-off to provide reassurance that the drafters of the ECRML had no such agenda. Consequently, "the purpose of Article 5 is primarily to forestall misinterpretation of the charter as a means of creating a right for linguistic groups to satisfaction of separatist claims". 77

However, the position at international law on the subject of state sovereignty and territorial integrity is complex and not always easy to determine. Sovereignty as a concept is controversial, relative and malleable and can mean different things in different contexts. ${ }^{78}$ International law recognises that the principle of non-intervention is not absolutely sacrosanct and can be overridden under certain circumstances. After all, another important principle within international law is that which recognises the right of peoples to selfdetermination. ${ }^{79}$ Indeed, the United Nations Charter provides that one of the primary purposes of the United Nations is "to develop friendly relations among nations based on respect for the principle of equal rights and self-determination of peoples". ${ }^{80}$ Although it has been said that "self determination cannot be used to further larger territorial claims in defiance of internationally accepted boundaries of sovereign states", it is also acknowledged that "it may be of some use in resolving cases of disputed frontier lines on the basis of the wishes of the inhabitants". ${ }^{81}$ Perhaps the right of nations within established states to unilateral secession has been held to be justified only in extreme cases. ${ }^{82}$ But reconciling the rights of national minorities to collective self-determination and the principles of state sovereignty and territorial integrity is by no means straightforward in international law. ${ }^{83}$

Adding to the complexity is the fact that, in recent times, there has been steady erosion of the sovereignty and territorial integrity principles due to an escalation in situations where the use of force against sovereign states has either been justified or has not been condemned by the UN. ${ }^{84}$ The use of force against terrorism in the name of collective security and international stability has provided disputed legitimacy for military interventions in Iraq and Afghanistan. The emergence of the humanitarian intervention justification for the use of force, particularly following NATO action in Kosovo in 1999, has made the advancement of human rights a potential basis for breaching the state sovereignty principle. This has set a precedent that potentially justifies intervention for the protection of minorities within states, particularly where such interference is necessary to preserve wider stability and where there is some risk of escalation in international conflict in the event of non-action. 85

These recent conflicts have thereby added to the wariness among states that wellestablished international law principles have been undermined and that the territorial

77 Woehrling, The European Charter, n. 21 above, p. 86.

78 For a detailed consideration of the significance of the concept of sovereignty within international law, see D Sarooshi, International Organisations and their Exercise of Sovereign Powers (Oxford: OUP 2005).

79 For further discussion, see K Knop, Diversity and Self-Determinations in International Law (Cambridge: CUP 2005).

80 UN Charter, Article 1(2).

81 M Shaw, International Law (Cambridge: CUP 2003), p. 445.

82 Reference Re Secession of Quebec (1998) 161 DLR (4th) 385, 438.

83 For a detailed conceptual analysis see TH Malloy, National Minority Rights in Europe (Oxford: OUP 2005). See also S Wheatley, Democracy, Minorities and International Law (Cambridge: CUP, 2005).

84 For reflections on the United Nations' position on the use of force, see JF Murphy, "Force and arms" in Joyner (ed.), n. 7 above, pp. 97-130.

85 See SD Krasner, "Sovereignty and intervention" in Lyons and Mastanduno, Beyond Westphalia?, n. 71 above, pp. $228-49$. 
integrity principle may be less robust than in the past. ${ }^{86} \mathrm{~A}$ lack of clarity and certainty in international law on the right to secession ${ }^{87}$ might have also fuelled anxiety that minority language campaigners could use linguistic claims as a pretext for the claims of national selfdetermination. If language rights are presented as an extension of human rights principles, then the unease and concern that either internal instability or external interference might be consequences of the recognition of such rights at some future point is understandable.

Yet, it is easy to exaggerate these concerns and anxieties. As one commentator has remarked, "sovereignty remains the central norm in the politics of international human rights. The international community, except in rare circumstances, does not have the right to exercise the power to intervene on behalf of human rights, nor has it been willing to do so." 88

But the need for Article 5 betrays the political sensitivity surrounding the advent of the ECRML. Of course, there is no provision within the ECRML that undermines states or promotes political secession for minorities. The authors of the ECRML clearly wished to respect state authority and to reassure that the ECRML has not in any way taken over states' powers to legislate for languages within their territories. It does not in any way derogate or diminish the right of states to do so. Indeed, for its provisions to be implemented and for them to acquire legal force, states must create domestic legislation for that purpose. We are thus reassured that ratification of the ECRML does not raise difficult constitutional questions about transfer of powers.

Article 5 is a device to depoliticise the treaty so that it cannot be interpreted in such a way that it is deemed to grant political power on any group. Linguistic minorities are not empowered to challenge state authority. ${ }^{89}$ Yet, somewhat paradoxically, the need to respect and observe the rights of minority language speakers arguably has an inherent political quality. Indeed, as was pointed out by one commentator, the European Union has "gone as far as to make respect for minority rights one of the 'political criteria' for admissions of new States to the Union". ${ }^{90}$ In some contexts, the political and the linguistic are inextricably linked as part of a comprehensive civil rights package. ${ }^{91}$ The ECRML's objective is the recognition and promotion of linguistic diversity within European states as a normalised component of European society and of membership of the European political community. ${ }^{92}$ The underlying rationale is to promote recognition of equality in diversity. 93 Linguistic minorities are afforded the status, obligations and privileges of full citizenship without sacrificing their linguistic identity. Of course, this vision of multilingual citizenship is intended to benefit the linguistic minority. However, it may also benefit the dominant group and, in particular, may serve the interests of preserving political hegemony and unity.

86 See, generally, C Gray, International Law and the Use of Force (Oxford: OUP 2004); also Y Dinstein, War, Aggression and Self-Defence (Cambridge: CUP 2005).

87 See A Buchanan, "The morality of secession" in W Kymlicka (ed.), The Rights of Minority Cultures (Oxford: OUP 2006), pp. 350-74.

88 See Donnelly, "State sovereignty", n. 71 above, pp. 115-46, at p. 115.

89 Woehrling, The European Charter, n. 21 above, p. 86

90 See F de Varennes, "The linguistic rights of minorities in Europe” in S Trifunovska (ed.), Minority Rights in Europe: European minorities and languages (The Hague: TMC Asser 2001), pp. 3-30, at p. 3.

91 See J Muller, "The European Charter for Regional or Minority Languages and the current legislative and policy contexts in the north of Ireland" in Dunbar and Parry, The European Charter, n. 20 above, pp. 219-37.

92 Kymlicka, Multicultural Citizenship, n. 2 above, pp. 174-6.

93 The approach is summed up by one commentator as follows: "With the politics of equal dignity, what is established is meant to be universally the same, an identical basket of rights and immunities; with the politics of difference, what we are asked to recognize is the unique identity of this individual or group, their distinctiveness from everyone else." See Taylor, "The politics", n. 3 above, at p. 38. 
As Kymlicka remarks, having recognised language as one of the key components of national identity:

if there is a viable way to promote a sense of solidarity and common purpose in a multinational state, it will involve accommodating, rather than subordinating national identities. People from different national groups will only share an allegiance to the larger polity if they see it as the context within which their national identity is nurtured, rather than subordinated. ${ }^{94}$

Instead of promoting political fragmentation along linguistic/national lines, an agenda for linguistic equality supports the concept of a multilingual and multinational unitary state. Accordingly, the grievance felt by the minority linguistic group, which might develop into an ambition for political autonomy and possible secession, is diffused if the concept of citizenship recognises and protects the linguistic identity of that group.

This vision of linguistic plurality that the ECRML offers is a means of recognising linguistic diversity within a homogenous society. It also encourages an approach whereby it is appreciated "that citizenship is not just a legal status, defined by a set of rights and responsibilities, but also an identity, an expression of one's membership in a political community".95 Therefore, citizenship that values and celebrates the maintenance of linguistic identity is also one that can facilitate the full membership of the political community of linguistic minorities. This concept of multilingual citizenship is also compatible with the principles of state sovereignty and territorial integrity. This, as is made clear in Article 5, is the agenda that the ECRML supports.

\section{Human rights and the ECRML}

The ECRML formally declares its relationship with the ECHR in Article 4, which contains an explicit declaration of non-derogation from the ECHR: "Nothing in this Charter shall be construed as limiting or derogating from any of the rights guaranteed by the European Convention on Human Rights." 96 According to the Explanatory Report, this paragraph "seeks to exclude the possibility that any of the provisions of the charter might be so interpreted as to detract from the protection accorded thereby to the human rights of individuals". 97 This declaration of compatibility is echoed elsewhere in the treaty. The ECRML also declares itself and its mission to be in communion with international human rights jurisprudence in its preamble:

The right to use a regional or minority language in private and public life is an inalienable right conforming to the principles embodied in the United Nations International Covenant on Civil and Political Rights, and according to the spirit of the Council of Europe's Convention for the Protection of Human Rights and Fundamental Freedoms. ${ }^{98}$

Why is there a need to declare this principle of compatibility, and is there a genuine potential for the ECRML to be interpreted in a way that contravenes the provisions of the ECHR? Of course, the ECHR governs the relationship between the individual and the state. It is a product of its period in history, a necessary innovation from a time when Europe and the world were recovering from the destruction and human suffering caused by those fascist regimes that had subsumed individual freedom and dignity in the name of

94 Kymlicka Multicultural Citizenship, n. 2 above, p. 189.

95 Ibid. pp. 191-2.

96 ECRML, Part 1, Article 4, para. 1.

97 ECRML, Explanatory Report, para. 54.

98 ECRML, Preamble. 
extreme collectivist ideologies. The ECHR was thus conceived as part of the international community's rejection of state totalitarianism and was created in order to lay down a series of minimum, fundamental and basic human rights intended to protect all human beings from future oppression. The history of its genesis is the key to understanding why the ECHR has an individualistic emphasis and why it is concerned with fundamental, individual human rights.

What impact does the ECHR have on minority language rights? Although the ECHR does not support linguistic freedom in the sense of facilitating language choice, it counters and prevents discrimination or degrading treatment towards individuals who belong to particular linguistic groups. ${ }^{99}$ It is thus an important contributor to the maintenance of the rights of linguistic minorities, even if those rights are mostly confined to the private sphere and are essentially a prohibition on discrimination. As one commentator observes:

State measures which have the effect of preventing the use of a minority language in private activities can be in breach of a number of well-established rights in international law [because] in the private sphere what are involved are in fact the application of basic individual human rights which impact in the arena of language. ${ }^{100}$

The ECHR is mainly a preventative instrument concerned with the maintenance of fundamental freedoms and rights, with laying down a bottom line below which states must not fall. The ECRML, on the other hand, is a totally different sort of instrument. It encourages and promotes positive initiatives and measures for the benefit of minority languages. ${ }^{101}$ Its promotion of minority languages is also couched in abstract rather than individualistic or human terms. Whereas the ECHR protects individual speakers of minority languages from human rights infringements, it does not provide active promotion of multilingualism as a social objective. In other words: "The right to free speech does not tell us what an appropriate language policy is."102

Even if it is accepted that there is a difference in emphasis, scope and objective between the two instruments, can the ECRML's distinction between the historical and the new minorities be reconciled with the universal emphasis in ECHR? Of course, there is the perspective that is sceptical of the very idea of universal human rights as proclaiming selfevident, objective and metaphysical truths about human values. ${ }^{103}$ The rights sceptics see it as a creation of a Western, neo-liberal, individualist mindset. Others doubt how ethereal human rights can permeate to the ground level and influence policy in real situations. In the linguistic context, some argue that the maintenance of language rights is more of a bottomup rather than a top-down process, one which depends more on the socio-political situation of the particular linguistic community than on general, universal and international policy initiatives. ${ }^{104}$ There can be no doubting the tensions that exist between declaring universal

99 See SM Poulter, "The rights of ethnic, religious and linguistic minorities" (1997) 3 EHRLR 254.

100 Indeed, "Government attempts to regulate the language used in the private sphere . . may run foul of the right to private and family life, freedom of expression, non-discrimination or the rights of persons belonging to a linguistic minority to use their language with other members of their group.": see de Varennes, "The Linguistic Rights", n. 90 above, at p. 9.

101 Kymlicka, Multicultural Citizenship, n. 2 above, p. 6.

102 Ibid. pp. 2-5.

103 For a critique of the idea of human rights, see M-B Dembour, Who Believes in Human Rights? Reflections on the European Convention (Cambridge: CUP 2006).

104 See X Arzoz, “Language rights as legal norms” 15(4) European Public Law (2009), pp. 541-74. 
rights and their implementation and monitoring in a particular domestic context. ${ }^{105}$ Yet, despite the scepticism, there is no denying the international consensus that supports human rights principles and the instruments that uphold them as important contributors in the task of protecting individuals against state oppression.

Despite the emphasis on historical languages, the ECRML does not restrict or invade the rights of individuals who speak dominant or official languages. Neither does it undermine the rights of those who speak other minority languages that are not protected by it. Its Explanatory Report specifically leaves the door open to further measures to deal with the linguistic interests of migrants:

The charter does not deal with the situation of new, often non-European languages which may have appeared in the signatory states as a result of recent migration flows often arising from economic motives. In the case of populations speaking such languages, specific problems of integration arise . . . these problems deserved to be addressed separately, if appropriate in a specific legal instrument. ${ }^{106}$

In recent years, the European Commission has recognised that the promotion of linguistic diversity and the development of a European language policy must include the official languages of the European Union, the indigenous minority languages, and also the languages of more recent migrant linguistic communities. ${ }^{107}$ Certainly, the ECRML is not an obstruction to the development of a comprehensive language policy that addresses the needs of new linguistic minorities.

The ECRML's particular emphasis on the promotion of indigenous minority languages does not infringe the universal principles of the ECHR, but builds on those principles so that minority language speakers enjoy a greater equality with speakers of official languages. ${ }^{108}$ Instead of representing a divergence from the values of the ECHR, the ECRML is a logical development on the ECHR and enhances its core principles. ${ }^{109}$ The difference is that the ECRML marks a shift from an anti-discriminatory, minimalist emphasis to an affirmative and pro-active approach towards linguistic minorities. Indeed, it is arguably a part of a well-established liberal political tradition that has sought to bring about the emancipation of minorities and those marginal groups who were historically excluded from mainstream society.

Although differential treatment always appears counter-intuitive to notions of universal equality, affirmative action or positive discrimination in the form of "group differentiated rights" for minority or neglected groups has also been recognised as being compatible with universal rights. ${ }^{110}$ This is because bringing about real social equality also requires special measures in favour of the minority or disadvantaged group. Provided that the groupdifferentiated right does not infringe other basic, individual, human rights and that it is

105 Some of these tensions are explored by Lord Hoffmann, "The universality of human rights" (2009) 125 LQR 416-32.

106 ECRML, Explanatory Report, para. 15.

107 See http://europa.eu/debateeurope/pdf/figel_062006_en.pdf.

108 Woehrling, The European Charter, n. 21 above, pp. 83-4.

109 See F de Varennes, "Language rights as an integral part of human rights - a legal perspective" in M Koenig and P de Guchteneire (eds), Democracy and Human Rights in Multicultural Societies (Aldershot: Ashgate 2007), pp. 115-25.

110 Kymlicka, Multicultural Citizenship, n. 2 above, pp 108-16. 
proportional to meet the deficit, then such affirmative action in favour of the minority language group can be justified. ${ }^{111}$

Indeed, such affirmative action is consistent with basic liberal and more universal principles of individual freedom, namely, in this case, the freedom to belong to a cultural group and the right to cultural (and linguistic) self-expression. Group-differentiated rights are thus necessary in order to provide a climate whereby the minority culture can function in the way the dominant culture takes for granted. ${ }^{112}$ Furthermore, it is also accepted that for human rights principles to impact on real, localised situations, a degree of adaptation to meet specific circumstances is also necessary. The local or specific implementation of universal rights principles requires practical measures, which ground or embed such universal rights in the particular context in which they are meant to impact and thereby promote a just society. 113 The ECRML can thus be appreciated as a dedicated measure to implement the human rights of indigenous linguistic minorities.

If so, the purported tension between universal human rights and more particular linguistic rights may be regarded as a conceptual fallacy. One observer claims that "the 'linguistic rights' of minorities actually refer to the application of universal human rights and freedoms in specific situations ... as part of an evolving, comprehensive framework based on respect for human worth and dignity". ${ }^{114}$ Indeed, such a view sees the relatively recent acknowledgment of the case for linguistic rights as being an inevitable consequence of the maturing of human rights jurisprudence. To quote:

It is therefore an often repeated error to assume that the protection of the rights of minorities is somehow inconsistent with or different from "individual" human rights. On the contrary, by being founded on the recognition of the intrinsic value of the human person's dignity and worth, human rights have gone beyond mere tolerance of human differences: respect of the individual includes valuing human diversity. ${ }^{115}$

The validity of this argument of compatibility between the particular emphasis of the ECRML and the universal emphasis of the ECHR could also be reinforced by the fact that the ECRML is not alone in its historical orientation and its focus on the rights of specific minority groups. Support for the notion of particular rights based on historical claims as distinct from universal rights can also be found in the United Nations Declaration on the Rights of Indigenous Peoples, which, after much negotiation, was adopted by the General Assembly of the United Nations on 13 September 2007.116 An important contributor to international human rights standards, it recognises the individual and collective rights of indigenous peoples as indigenous peoples. ${ }^{117}$

For example, it recognises the right to unrestricted self-determination, ${ }^{118}$ an inalienable collective right to the ownership, use and control of lands, territories and other natural

111 See J Castellino, "Affirmative action for the protection of linguistic rights: an analysis of international human rights; legal standards in the context of the protection of the Irish language" (2003) 25(1) Dublin University Law Journal 1-43.

112 Kymlicka, Multicultural Citizenship, n. 2 above, p 126.

113 For observations in the context of Northern Ireland, see C Harvey and D Russell, "A new beginning for human rights protection in Northern Ireland" (2009) 6 EHRLR 748-67.

114 See de Varennes, "The linguistic rights", n. 90 above, p. 4.

115 Ibid. p. 29.

116 United Nations Declaration on the Rights of Indigenous Peoples, UN General Assembly Resolution 61/295.

117 Ibid. para. 22.

118 Ibid. Article 3. 
resources, ${ }^{119}$ rights to political, social, cultural ${ }^{120}$ and educational institutions ${ }^{121}$ and to protection of cultural and intellectual property. ${ }^{122}$ Article 13 explicitly refers to linguistic rights, and states that "indigenous peoples have the rights to revitalize, use, develop and transmit to future generations their histories, languages, oral traditions, philosophies, writing systems and literatures". Article 14 refers to the rights to "education in their own languages" and Article 16 to "media in their own languages". Such rights are also incorporated within the cultural rights to which the declaration repeatedly refers and which it protects. ${ }^{123}$

Like the ECRML, the declaration draws on notions of historical injustice in support of its rationale:

indigenous peoples have suffered from historic injustices as a result of, inter alia, their colonization and dispossession of their lands, territories and resources, thus preventing them from exercising, in particular, their right to development in accordance with their own needs and interests. ${ }^{124}$

Similar to the ECRML's emphasis on recognising the diversity of circumstances facing minority languages, it recognises that every indigenous community faces its own particular challenges and that "the situation of indigenous peoples varies from region to region and from country to country, and that the significance of national and regional particularities and various historical and cultural backgrounds should be taken into consideration". ${ }^{125}$

Although it is not legally binding on states, and so does not impose legal obligations on governments, its adoption was not without some dissent among some of the UN members who expressed reservation at the notion of recognising the collective human rights of certain groups. ${ }^{126}$ This was seen to run counter to the universal emphasis in other international human rights instruments and to compromise the universal basis upon which the very idea of human rights is based. Without doubt, the declaration brings to the fore the complicated relationship between international law, human rights and claims for reparation based on historical injustice. Yet, that relationship is a real one because "Striving for truth and justice, which includes reparation, is part of a system based on the rule of law and on the equal dignity of all human beings." 127

Both the declaration and the ECRML are specific in emphasis and engaged with historically based rights or measures for specific minority groups or languages. Both also highlight the fact that, with group or minority rights, the engagement of history is often unavoidable because group identity and claims for justice can be so firmly grounded in historical perception. ${ }^{28}$ However, recognising the special rights of groups is part of an evolving international human rights framework, which acknowledges the diversity of human existence and which seeks to facilitate justice for all human beings by taking into account their particular identity. Human rights can thus incorporate the right of individuals to express cultural and linguistic identity as individuals and collectively within their community. Even if such special rights may be conceptually problematic if treated as

119 UN Declaration, n. 116 above, Articles 26-30.

120 Ibid. Article 5.

121 Ibid. Article 14.

122 Ibid. Article 31.

123 Ibid. Articles 8, 11 and 15.

124 Ibid. para. 6 .

125 Ibid. para. 23.

126 http://www.un.org/News/Press/docs/2007/ga10612.doc.htm.

127 See F Francioni, "Reparation for indigenous peoples: is international law ready to ensure redress for historical injustices?" in F Lenzerini (ed.), Reparation for Indigenous Peoples (Oxford: OUP 2008), pp. 27-45, at p. 45.

128 See M Bentley, Modern Historiography: An introduction (London: Routledge 1999), pp. 156-8. 
universal human rights, it is recognised that such "special" or differentiated rights are necessary to implement the human rights of groups in practice. It is further recognition that, simply, "differentiated groups may require additional rights to enable them to overcome specific obstacles which prevent them from being able to exercise their human rights as effectively as others". 129

\section{Conclusion}

Its policy towards its linguistic minorities forms a key element of Europe's policy on common citizenship, because the recognition of linguistic diversity is an essential prerequisite of a coherent and harmonious European society. Minority language policy plays a key role in determining the way in which minority linguistic groups participate in society. The European Commission acknowledges that a multilingual Europe demands "the peaceful co-existence of people from many different language communities", and that the protection of cultural identity and linguistic diversity is the key to greater European unity. ${ }^{130}$

Is reconciling the ECRML's particular emphasis on historical languages with universal human rights a case of trying to square the circle? Perhaps there is too much focus on resolving conceptual dilemmas and on finding theoretical hooks on which to hang worthy social values and objectives. It distracts from the need for these international instruments and their implementation mechanisms to impact on actual situations and to have practical benefit. The ECRML is a detailed and specific instrument that seeks to emancipate particular linguistic minorities who were historically marginalised. That it is tailor-made to facilitate the rights of historical languages does not mean that it demeans or undermines the validity of the rights of other marginalised groups. Neither does it act as an instrument to promote political secession.

Indeed, the ECRML is a particularly European recognition of the need to respect the right to a cultural and linguistic identity and to express that identity freely within a politically homogenous society. Although its particular historiography might seem unattractive for the more universally orientated palate, in its task of setting standards and promulgating international norms for the protection of regional or minority languages, the ECRML encourages constructive measures that promote linguistic diversity in a way that is compatible with international law principles of sovereignty and territorial integrity. It is, in essence, Europe's solution to the challenge of managing its own particular cultural and linguistic patrimony. Indeed, it is the only international instrument that provides a comprehensive road-map towards the ideal of the multilingual unitary state.

129 See S Greer, "Being 'realistic' about human rights” (2009) 60(2) NILQ 147-61, at p. 150.

130 See http://europa.eu/debateeurope/pdf/figel_062006_en.pdf. 